\title{
Proximate Phytochemical analysis of Corallocarpus epigaeus (Arn.) Cl rhizomes and Vernonia anthelmintica willd seeds
}

\author{
Kishor A. Kothawade ${ }^{1 *}$ and Dr. A.R. Siddiqui ${ }^{2}$ \\ 1. Y. B. Chavan College of Pharmacy, Aurangabad, Maharashtra, India \\ 2. Bhagwan College of Pharmacy, Aurangabad, Maharashtra, India
}

\begin{abstract}
The proximate phytochemical analysis of Corallocarpus epigaeus (Arn.) Cl rhizomes and Vernonia anthelmintica wild seeds carried out using standard reference methods. The result shown the seeds of Vernonia anthelmintica had significant values of ash content, moisture content, total solid content and extractives as compared to $C$. epigaeus rhizomes. The qualitative chemical test indicated that the presence of alkaloid, flavonoid, saponin, amino acids and proteins in C. epigaeus rhizomes extract while carbohydrate, flavonoid, saponin, amino acids and proteins were found in the $V$. anthelmintica seeds extracts. Among all the extract, aqueous extract of $V$. anthelmintica seeds contains highest amount of total flavonoid content followed by aqueous extract of $C$. epigaeus rhizomes. The presence of high secondary metabolites in the $C$. epigaeus (Arn.) $\mathrm{Cl}$ rhizomes and $V$. anthelmintica seeds willd seeds indicated that if the plant is subjected to further research such as identification and characterization of plant, bioactive compounds with strong biological activities may be isolated and novel compounds may also be identified.
\end{abstract}

Keywords: Ash value, extractive value, total flavonoids content.

Article Info: Received 06 July 2019; Review Completed 04 Aug 2019; Accepted 18 Aug 2019; Available online 25 August 2019

Cite this article as:

Kothawade KA, Siddiqui AR, Proximate Phytochemical analysis of Corallocarpus epigaeus (Arn.) Cl rhizomes and Vernonia anthelmintica willd seeds, Journal of Drug Delivery and Therapeutics. 2019; 9(4-s):1203-1206 DOI: http://dx.doi.org/10.22270/jddt.v9i4-s.3916

*Address for Correspondence:

Kishor A. Kothawade, Y. B. Chavan College of Pharmacy, Aurangabad, Maharashtra, India

\section{INTRODUCTION}

Because of the presence of phytochemical constituents, the medicinal plants are useful for both healing and curing of human diseases. More people around the world have turned to the use of medicinal plant products in the healthcare system in recent years. The growing need for alternative medicine has resulted in the use of natural plant remedies generating an immense need for knowledge on the properties and uses of medicinal plants; resulting in development of natural product markets and interest in conventional medicinal systems. It is necessary to properly integrate the modern scientific techniques and traditional knowledge. Therefore, the role of medicinal plants in the mainstream health care system in solving healthcare problems is becoming increasingly stressed. For this, it is important to establish standardization of herbal raw materials and herbal formulations using systematic and well-designed methodologies ${ }^{1-2}$.

Known in Gujarat as the Jungalisuran, Corallocarpus epigaeus (Arn.) Cl. (Cucurbitaceae). It is distributed throughout tropical Africa, region of the Persian Gulf and India. The root has a bitter principle that is allied with bryonin. A phydroxybenzoyl ester, named epigaeusyl ester, a sesterpene lactone, viz. corallocarpscalaride, a pyridine carboxylic ester, designated as corallocarpeonyl ester. It has a bitter and sub-acidic taste and has alterative and laxative properties and is used in syphilis, rheumatism, later dysentery stages ${ }^{3}$. Vernonia anthelmintica Willd, commonly known as Vakuchi; is a member of the Asteraceae family. It is an annual herb spread all over Indialt has been commonly used in the treatment of certain illnesses such as asthma, kidney disorders, inflammatory swelling, leucoderma, worm infection and seizures. The possession of various therapeutic activities was noticed, viz. Anti-inflammatory, anti-arthritic, antidiabetic, antibiotic, antibacterial, anti-cancer and many more 4 .

Our research aims at standardizing the drugs as well as analyzing the presence or absence of different phytochemicals in both medicinal plants and justifying their use as a medicinal plant. 


\section{MATERIAL AND METHODS}

\section{Chemicals and reagents}

Methanols, aluminum trichloride, quercetin, toluene, ethyl acetate, formic acid are used for the experiment.

\section{Collection and authentication of plant material}

Plant materials, such as rhizomes of $C$. epigaeus (Arn.) $\mathrm{Cl}$ and seeds of $V$. anthelmintica willd were collected from rural area of Tirupati, India, The plants were identified and authenticated from Department of Botany, Sri Vankateswara University, Tirupati, India. A voucher specimen (1528 and 1124) of the plant was deposited in the department.

\section{Extraction of plant material}

About $50 \mathrm{~g}$ of defatted dried plant material of $V$. anthelmintica and $C$. epigaeus were exhaustively extracted with methanol and water solvent using maceration method. After extraction, material was subjected to the filtration, filtrate was collected and subject to concentrate on water batch. Finally the percentage yields were calculated on air dried basis $(\% w / w)$.

\section{Proximate analysis $5-8$}

\section{Determination of moisture content and total solid content:}

The percentage of moisture content for both raw plant materials has been calculated because any excess water in medicinal plant materials would promote microbial growth, presence of fungi or insects and cause degradation after hydrolysis. The percentage of moisture content in a previously dried and tared flat weighing container was measured gravimetrically in which $5 \mathrm{~g}$ of precisely weighted air-dried material was put in. The sample was dried in an oven at $100^{\circ} \mathrm{C}-105^{\circ} \mathrm{C}$ until 2 consecutive weighing did not differ by more than $5 \mathrm{mg}$. Total solid content was determined by the following formula:

$$
\text { Total solids }(\%)=100 \text { - Moisture (\%) }
$$

\section{Determination of ash values:}

These are used to determine a crude drug's consistency and purity, and to establish its identity. That medication contains definite amounts of inorganic radicals, such as phosphates, carbonates and sodium silicates, potassium, magnesium, calcium etc. Quantitative determination in terms of different ash values therefore helps in their standardization as well as in determining foreign inorganic matter that is present as impurity.

\section{Determination of Total ash:}

Four grams of the powdered material were precisely weighed and put in a crucible of silica which was previously ignited and tared. The material was spread out in an even layer and ignited by gradually raising the heat to a temperature of $500-600^{\circ} \mathrm{C}$ until it was white, indicating the carbon absence. The material was refrigerated and measured in a desiccator. The total ash content in the airdried material was calculated in $\mathrm{mg} / \mathrm{g}$.

\section{Determination of Acid-insoluble ash:}

In addition, $25 \mathrm{ml}$ of hydrochloric acid was applied to the crucible containing complete ash, covered with a watch glass and gently boiled for $5 \mathrm{~min}$. The watch glass was rinsed with $5 \mathrm{ml}$ of hot water and added the liquid to the crucible. The insoluble matter was collected on an ashless filter paper and washed with hot water until neutral to the filtrate. The insoluble material left on the filter paper was transferred to the original crucible, dried on a hot plate, and ignited to weight constant. The residue was allowed to cool for $30 \mathrm{~min}$ in a suitable desiccator, then weighed without delay. The amount of acid-insoluble ash in air-dried material was measured in $\mathrm{mg} / \mathrm{g}$.

\section{Determination of extractive values:}

The extractive value gives an idea of the essence of the chemical constituents present in the crude drug; which is useful for determining components extracted from the solvent used for extraction as well as for evaluating a crude drug.

\section{Determination of water soluble extractives:}

$5 \mathrm{gm}$ of powdered drug was taken in conical flask, and then $100 \mathrm{ml}$ of water was added. After that flasks were closedwith the help of the cotton plug; the mixture wasshaken after regular interval of time withouttouching the solution on to the cotton plug. The mixture was kept for $24 \mathrm{hrs}$ (with regular shaking). After the period of $24 \mathrm{hrs}$ thesolution was filtered out by using whatman filter paper and collected the filtrate. Emptyevaporating dish was taken and weighed the dishand noted down. Then $25 \mathrm{ml}$ of $5 \%$ solution ofeach of drug was taken in evaporating dish. Thenthe evaporating dish was heated until the dampmass was formed. Then cooled the evaporatingdish and weighted it. Difference of evaporatingdish containing damp mass and emptyevaporating dish was taken and directlycalculated the water soluble extractive value.

\section{Determination of alcohol soluble extractives:}

$5 \mathrm{gm}$ of powdered drug was taken in conical flask, and then $100 \mathrm{ml}$ of alcohol (99\%) was added. After those flasks were closedwith the help of the cotton plug; the mixture was shaken after regular interval of time without touching the solution on to the cotton plug. The mixture was kept for 24 hrs (with regular shaking). After the period of $24 \mathrm{hrs}$ thesolution was filtered out by using whatman filter paper and collected the filtrate. Empty evaporating dish was taken and weighed the dishand noted down. Then $25 \mathrm{ml}$ of $5 \%$ solution ofeach of drug was taken in evaporating dish. Then the evaporating dish was heated until the dampmass was formed. Then cooled the evaporating dish and weighted it. Difference of evaporating dish containing damp mass and empty evaporating dish was taken and directlycalculated the alcohol soluble extractive value.

\section{Qualitative phytochemical analysis}

Preliminary qualitative phytochemical analysis was carried out to identify the secondary metabolites such as alkaloids, carbohydrates, glycosides, tannins, and phenolic compounds, flavonoids, fixed oils, saponins, proteins and amino acids, and steroids present in the various alcoholic and aqueous extracts of Corallocarpus epigaeus and Vernonia anthelmintica ${ }^{9}$.

\section{Quantitative estimation of phytochemical constituents ${ }^{10}$}

\section{Estimation of Total Flavonoids Content (TFC)}

Determination of TFC was based on measurement of theintensity of red color complex formed due to reaction between flavonoids and aluminum trichloride $\left(\mathrm{AlCl}_{3}\right)^{11}$. Briefly, the $\mathrm{AlCl}_{3}$-methanolic solution $(1 \mathrm{~mL}, 2 \% \mathrm{w} / \mathrm{v}$ ) wasmixed to various diluted extracts or standard (1 mL) and allowed to stand for $1 \mathrm{~h}$ at $25 \pm 2^{\circ} \mathrm{C}$ before the absorbance was measured at $\lambda_{\max } 420 \mathrm{~nm}$ against blank using ultraviolet visible (UV-Vis) spectrophotometer (Shimadzu 1800, Kyoto, Japan). Extract samples were evaluated at a final concentration of $1 \mathrm{mg} / \mathrm{mL}$. The $\mathrm{TFC}$ was compared to quercetin equivalent $(\mathrm{QE})(\mathrm{mg} / 100 \mathrm{mg}$ of extract) using 
theregression equation $y=0.040 \mathrm{X}+0.009, \mathrm{r}^{2}=0.999$, where $\mathrm{x}$ is the absorbance and $\mathrm{y}$ is the $\mathrm{QE}$.

\section{Thin layer chromatography (TLC)}

Presence of flavonoid in $V$. anthelmintica and $C$. epigaeus drug were determination by using TLC study using quercetin as standard ${ }^{12}$. The selected extracts were prepared with the respective solvent and made up to $10 \mathrm{ml}$ in different test tubes. Then the extracts were taken in a capillary tube and it was spotted in preparative TLC plates coated with silica gel G. The plates were developed in TLC chamber previously saturated with toluene: ethyl acetate: Formic acid (5:4:1) solvent systems. The different spots developed in solvent system were identified by means of detecting agent and the $R_{f}$ value are correspondingly calculated.

\section{RESULTS AND DISCUSSION}

Aqueous and methanolic extract of $V$. anthelmintica showed $3.8 \% \mathrm{w} / \mathrm{w}$ and $3.4 \% \mathrm{w} / \mathrm{w}$, percentage yield respectively while aqueous and methanolic extract of $C$. epigaeus showed $4.1 \% \mathrm{w} / \mathrm{w}$ and $2.3 \% \mathrm{w} / \mathrm{w}$, percentage yield, respectively.
Percentage yield of both plants are given in Table 1 . The physico-chemical parameters are helpful in judging the purity and quality of the drug. The percentage of activeprinciples in the plant is determined only in the dry condition. Hence the parameters determined for proximate analysis include moisture content,total solid content,ash value and extractive value content of the both drugs drug. Results of each parameter evaluated are given in Table 2. The present study of phytochemical analysis of two different extracts methanol and Aqueous of both plants has suggested the presence of various phytocompouds as shown in Table 3 . Total flavonoids content (TFC) present in both of the plant extracts as quercetin equivalent (QE), respectively; have been determined using spectrophotometer. Aqueous extract of $V$. anthelmintica contain more amount of flavonoid content rather than methaolic extract. However in case of $C$. epigaeu methanolic extract does not contains flavonoids. Amount of TFC present is various extracts of both plants are given in Table 4. TLC of the extract proves that both of the plants extracts contain flavonoids (quercetin) along with other compounds (Table 5 and Figure 1).

Table 1: Yield (\%) of Corallocarpus epigaeus and Vernonia anthelmintica extracts

\begin{tabular}{ccc}
\hline Drug & $\begin{array}{c}\text { Percentage Yield }(\% w / w) \text { of } \\
\text { Methanolic extract }\end{array}$ & $\begin{array}{c}\text { Percentage Yield (\% } w / w) \text { of } \\
\text { Aqueous extract }\end{array}$ \\
\hline Corallocarpus epigaeuse & 2.3 & 4.1 \\
Vernonia anthelmintica & 3.4 & 3.8 \\
\hline
\end{tabular}

Table 2: Physiochemical analysis of crude drugs

\begin{tabular}{lcc}
\hline \multicolumn{1}{c}{ Parameter } & C. epigaeus & V. anthelmintica \\
\hline Moisture content & $0.47 \% \mathrm{w} / \mathrm{w}$ & $0.68 \% \mathrm{w} / \mathrm{w}$ \\
Total solid content & $99.53 \% \mathrm{w} / \mathrm{w}$ & $99.32 \% \mathrm{w} / \mathrm{w}$ \\
Total ash & $2.83 \% \mathrm{w} / \mathrm{w}$ & $3.67 \% \mathrm{w} / \mathrm{w}$ \\
Acid insoluble ash & $0.42 \% \mathrm{w} / \mathrm{w}$ & $1.08 \% \mathrm{w} / \mathrm{w}$ \\
Alcohol soluble extractive value & $5.2 \% \mathrm{w} / \mathrm{w}$ & $4.7 \% \mathrm{w} / \mathrm{w}$ \\
Water soluble extractive value & $4.3 \% \mathrm{w} / \mathrm{w}$ & $3.9 \% \mathrm{w} / \mathrm{w}$ \\
\hline
\end{tabular}

Table 3: Phytochemical screening of extracts of Corallocarpus epigaeus and Vernonia anthelmintica extracts

\begin{tabular}{l|cc|cc}
\hline \multicolumn{1}{c}{ Constituents } & \multicolumn{2}{c|}{ C. epigaeus } & \multicolumn{2}{c}{ V. anthelmintica } \\
\cline { 2 - 5 } & $\begin{array}{c}\text { Methanol } \\
\text { extract }\end{array}$ & $\begin{array}{c}\text { Aqueous } \\
\text { extract }\end{array}$ & $\begin{array}{c}\text { Methanol } \\
\text { extract }\end{array}$ & $\begin{array}{c}\text { Aqueous } \\
\text { extract }\end{array}$ \\
\hline Alkaloids & - & + & - & - \\
Glycosides & - & - & - & - \\
Flavonoids & - & + & + & + \\
Saponins & + & + & + & - \\
Phenolics & - & - & + & + \\
Amino Acids & + & - & + & + \\
Carbohydrate & + & + & + & + \\
Proteins & + & - & + & + \\
Diterpenes & - & - & + \\
\hline
\end{tabular}


Table 4: Estimation of TPC and TFC

\begin{tabular}{lcc}
\hline Drug & \multicolumn{2}{c}{ TFC } \\
& \multicolumn{2}{c}{ (QE mg/ 100 mg of extract) } \\
\cline { 2 - 3 } & Methanolic extract & Aqueous Extract \\
\hline C. epigaeus & - & 1.127 \\
V. anthelmintica & 0.780 & 2.082 \\
\hline
\end{tabular}

Table 5: Thin layer chromatography of extracts of $C$. epigaeus and $V$. anthelmintica

\begin{tabular}{lccc}
\hline \multicolumn{1}{c}{ Extract } & \multicolumn{3}{c}{ Rf Value } \\
\cline { 2 - 4 } & Day Light & Short U.V. & Long U.V. \\
\hline Quercetin & 0.51 & 0.51 & 0.51 \\
Aqueous extract of C. epigaeus & - & - & 0.36 \\
Methanol extract of V. anthelmintica & 0.39 & 0.39 & 0.38 \\
& 0.51 & 0.48 & 0.51 \\
& & 0.51 & 0.68 \\
Aqueous extract of V. anthelmintica & 0.51 & 0.79 & 0.75 \\
& 0.62 & 0.57 & 0.79 \\
& & 0.51 & 0.57 \\
& & 0.49 & 0.51 \\
\hline
\end{tabular}
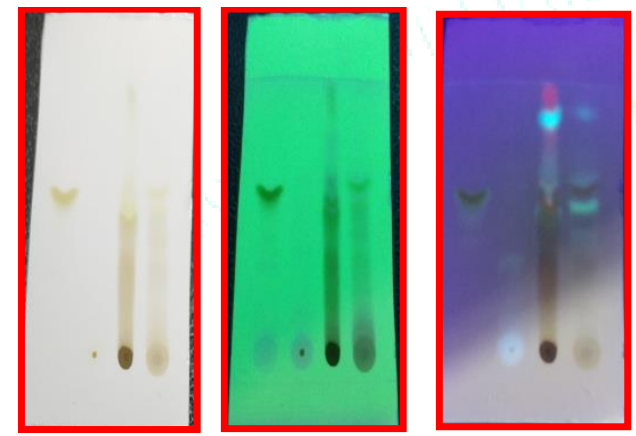

Normal Light Short U.V Long U.V

Figure 1: Photograph of T.L.C (Quercetin)

$1^{\text {st }}$ spot standard (Quercetin); $2^{\text {nd }}$ spot $C$. epigaeus aqueous extract; $3^{\text {rd }}$ spot $V$. anthelmintica methanol extract; $4^{\text {th }}$ spot $V$. anthelmintica aqueous extract.

\section{CONCLUSION}

From the result of proximatephytochemical analysis, concluded that the $V$. anthelmintica and $C$. epigaeus plants were found to contain phytoconstituents like alkaloids, flavonoids, saponins and tannins which are reported clinically to combat various diseases and disorders in human beings. This study prompted us for the identification, isolation, characterization and investigation novel bioactive compounds.

\section{CONFLICTS OF INTEREST}

No conflicts of interest

\section{REFERENCES}

1. Ekor M. The growing use of herbal medicines: issues relating to adverse reactions and challenges in monitoring safety. Frontiers in pharmacology. 2014; 4:177.
2. Sofowora A, Ogunbodede E, Onayade A. The role and place of medicinal plants in the strategies for disease prevention. African Journal of Traditional, Complementary and Alternative Medicines. 2013; 10(5):210-29.

3. Ishnava K, Kotadia R, Patel S. Nutritional Properties and Chemical Composition of Corallocarpus epigaeus (Arn.) Cl: As Remedy to Control Diabetes mellitus. Chiang Mai Journal of Science. 2015; 42(4):806-15.

4. Manvar MN, Desai TR. Vernonia anthelmintica Willd.: An overview on phytopharmacological properties. Inventi Rapid: Ethnopharmacol. 2012; 4:1-4.

5. Shukla RK, Painuly D, Shukla A, Kumar V, Singh J, Porval A, Vats S. Physical evaluation, proximate analysis and antimicrobial activity of Morus Nigra seeds. International Journal of Pharmacy and Pharmaceutical Sciences. 2015; 7(1):191-7.

6. Aborisade AB, Adetutu A, Owoade AO. Phytochemical and Proximate Analysis of Some Medicinal Leaves. Clinical Medicine Research. 2017; 6(6):209.

7. Bansode TS, Salalkar BK. Phytochemical analysis of some selected Indian medicinal plants. Int J Pharm Bio Sci. 2015; 6(1):550-6.

8. Bhargava VV, Saluja AK, Dholwani KK. Detection of heavy metal contents and proximate analysis of roots of Anogeissus latifolia. Journal of Pharmacognosy and Phytochemistry. 2013; $1(6)$.

9. Harborne JB, Williams CA. Advances in flavonoid research since 1992. Phytochemistry. 2000; 55:481-504.

10. Modi A. Phytochemical analysis, antioxidant activity, and hepatoprotective effects of Zizyphus xylopyrus (Retz.) Willd leaves extracts against carbon tetrachloride-induced hepatotoxicity in in vitro and in vivo models. International Journal of Green Pharmacy. 2017; 11(01).

11. Singh SK, Chouhan HS. Phytochemical analysis, antioxidant and anti-inflammatory activities of Phyllanthus simplex. J Ethnopharmacol 2011; 137:1337-44.

12. Sonam M, Singh RP, Pooja S. Phytochemical screening and TLC profiling of various extracts of Reinwardtia indica. Inter J of Pharma and Phytochem Res. 2017; 9(4):523-7. 